Memórias de Nelson Rodrigues: Elementos Conectores entre Jornalismo e Dramaturgia

a I I I I I I I I I I I I I I I I I I I I I I I

José Francisco Quaresma Soares da Silva

Edina Regina Pugas Panichi

Artigo recebido em: 08/11/2018

Artigo aprovado em: 25/04/2019 


\section{Memórias de Nelson Rodrigues: Elementos Conectores entre Jornalismo e Dramaturgia}

Nelson Rodrigues' memories: Connecting Elements between Journalism and Drama

José Francisco Quaresma Soares da Silva* Edina Regina Pugas Panichi**

Resumo: Em 1967, Nelson Rodrigues estreia a coluna Memórias no jornal Correio da Manhã. O escritor reconhecia o espaço do jornal como laboratório para a construção de vários de seus textos dramáticos. O objetivo deste trabalho é destacar e analisar suas vivências como elementos formadores da personalidade autoral do jornalista, material que reverbera na constituição dos textos narrativos e se ajusta na construção de sua obra dramática.

Palavras-chave: Jornalismo. Memórias. Narrativa. Dramaturgia.

Abstract: Abstract: In 1967, Nelson Rodrigues debuts at the column Memórias in the newspaper Correio da Manhã. The writer acknowledge the space of the newspaper as a laboratory for the construction of several of his dramatic texts. The aim of this work is to highlight and analyze his experiences as forming elements of the journalist's authorial personality, a material that reverberates in the constitution of the narrative texts and fits in the construction of his dramatic work.

Keywords: Journalism. Memories. Narrative. Dramaturgy.

* Bacharel em Artes Cênicas e Mestre em Educação. Doutorando em Estudos da Linguagem - PPGEL/UEL. Professor Efetivo do Instituto Federal do Paraná - Campus Jacarezinho.

** Doutora em Letras pela Universidade Estadual Paulista Júlio de Mesquita Filho. Pós-Doutorado pela Universidade Federal de Minas Gerais. Atualmente é professora colaboradora da Universidade Estadual de Londrina. 


\section{Introdução}

No ano de 1967, aos 55 anos, Nelson Rodrigues aceitou o convite para escrever suas memórias no jornal carioca Correio da Manhã. Na época, o jornalista já era uma estrela da imprensa e mantinha vínculos com $O$ Globo e o Jornal dos Sports, além de participar de programas na TV Globo. Seu prestígio era tamanho que pôde continuar exercendo as mesmas funções, concomitantemente e sem interrupção, nos variados órgãos de comunicação. Entretanto, do ponto de vista de Nelson Rodrigues, havia certa mágoa, pois o jornal de Roberto Marinho não lhe havia sido solidário na luta que travava com o ministro da Justiça do primeiro governo do golpe militar, que proibiu o seu romance $O$ Casamento, que alcançava marca expressiva entre os mais vendidos da época. Então, numa atitude de revanche, na qual estavam mesclados sentimentos de indignidade e traição, foi escrever suas memórias no jornal que havia sido o primeiro emprego de seu pai, Mário Rodrigues, quando este aportou no Rio de Janeiro, no ano de 1916 (CASTRO, 1992, p. 349-355).

Embora precoce para escrever memórias, o fato é que Nelson Rodrigues havia passado os últimos quarenta anos nas redações dos mais importantes jornais e revistas do país, e conforme Castro (1992, p. 354), perpassou "todas as revoluções gráficas, estilísticas e empresariais da imprensa naquele período" e, mesmo na condição de coadjuvante, acompanhou de perto muitas das transformações políticas do Brasil. Durante essa vivência, provou do sucesso e do fracasso em vultosa escala, e por isso tinha o que contar e sabia como fazer. Ainda, segundo Castro (1992), ninguém escrevia de modo mais 
articulado, polêmico e engraçado, num impressionante currículo a envolver reportagem de polícia, futebol, crítica, crônica, conto, folhetim, até mesmo consultório sentimental, escrito em seu nome, com o nome dos outros, e mesmo com os artifícios de pseudônimos fossem femininos ou masculinos, como Suzana Flag, Mirna e Braz Buriti (STEEN, 2008). Por todas essas referências, com indisfarçado orgulho o jornal Correio da Manhã anunciou por toda uma semana, anterior ao lançamento e em chamadas de primeira página, as Memórias de Nelson Rodrigues, cuja estreia se deu em fevereiro de 1967, na primeira página do segundo caderno, do qual José Lino Grünewald era o editor, e seriam, em princípio, o que o título dizia: reminiscências autobiográficas (CASTRO, 1992, p. 354).

Entre os meses de fevereiro e maio de 1967, Rodrigues publicou oitenta crônicas memorialistas, nas quais, antecipadamente, prometia não esconder nada, em confidências nada edificantes, pois segundo ele havia vivenciado "um arsenal de fatos incríveis numa vida que não faz graça para ninguém, pois teve tudo e sofreu tudo" (RODRIGUES, 2012, p. 48).Do total da produção escrita, as 39 primeiras foram organizadas em capítulos na coletânea Memórias - A menina sem estrela, lançada em 1967 pela editora do Correio da Manhã. Foi um período profícuo, mas bastante curto, porque no final do mesmo ano, Nelson Rodrigues transferiria seus textos memorialistas para o jornal $O$ Globo, e a partir de então, seriam apresentadas sob o título de Confissões (RODRIGUES, 2009, p. 12).

Este trabalho tem como objetivo destacar e analisar as vivências infantis e juvenis como amálgamas formadoras da personalidade autoral do jornalista e escritor Nelson Rodrigues, material que reverbera na construção dos textos narrativos de 
cunho memorialista e se ajusta na construção de sua obra narrativa e dramática. Tem como base metodológica a análise dos processos de criação artística, em consonância com os pressupostos teóricos da Crítica Genética. Tais processos são explicados por elementos conectores e imbricações, chaves cujas qualidades são designadas como assombros e deslumbramentos experienciados pelo escritor, revividos quando da escrita de suas memórias a envolver a infância e a adolescência autoral, por vezes alcançando parte de sua juventude. Destaca-se o modo como os elementos conectores, articulados como base interativo-discursiva, transitam processualmente entre os vários gêneros textuais.

\section{Assombros e Deslumbramentos}

Os estudos da Crítica Genética, os quais regem os pressupostos teóricos e metodológicos aplicados nesta análise, surgem na França, em 1968.É relevante destacar que no início dos anos 1970, quando a Crítica Genética começou a se desenvolver, o foco de discussão estava voltado ao texto e seu desenvolvimento, produção textual e sujeito da escritura, isto é, a análise centrava basicamente no estudo do manuscrito autógrafo, o que iria permitir a reconstituição da gênese dos escritos. No Brasil, esta metodologia foi introduzida em 1985 por Philippe Willemart. A Crítica Genética adquiriu estatuto de disciplina independente devido ao seu propósito definido, um campo demarcado de estudo com fôlego e visão prospectiva para examinar outras linguagens artísticas. Da análise antes posta nos manuscritos literários, ampliam-na a uma abrangência que alcança a discussão dos processos de criação em outras linguagens, quando 
assume deliberadamente sua vocação transartística, quando surge o desejo em ver desvendado os segredos das artes plásticas, do cinema, da dança, do teatro, alcançando outras modalidades artísticas, chegando ao fotojornalismo, à publicidade etc. (SALLES, 2008, 2017).

Se no ofício de jornalista e escritor, para Nelson Rodrigues, a criação era o principal motivo, pode-se dizer que na infância, perceber e observar eram movimentos precisos e constantes, o que fazia dele um singular menino-existencialista. As primeiras lembranças às quais o autor se refere têm como lugar sua terra natal - Recife. Um mundo tão pregresso onde há apenas o sentido do olfato, e, no qual, Rodrigues vivencia suas primeiras experiências regressivas que o fazem refletir, posteriormente, quando do registro de suas memórias e confissões, como se raptado por "movimentos proustianos" em “processos regressivos e fatais" (RODRIGUES, 2009, p. 24).

Desde a longínqua infância, as memórias do autor vão identificar experiências sensoriais nos variados espaços de sua convivência. Isso ocorre na praia pernambucana do Recife, onde cheiros e sabores se misturam na descoberta do mundo, ou, já no Rio de Janeiro, quando chegou aos quatro anos de idade, em 1916, e foi deslumbrado ante a sonoridade da valsa do Conde de Luxemburgo, de Lehar, que tocava na vitrola do vizinho. Tempos depois, cairá arrebatado pela visão do umbigo desnudo da odalisca no bloco de carnaval, assombro que se expandirá ao descobrir que a dona do umbigo revelado por entre "a modesta nesga de carne, insinuada pelo decote abdominal" e causadora de sua ardente paixão, ronda o universo da "mais antiga das figuras femininas: - a adúltera". Essas memórias, e outras igualmente potentes, são resgatadas pelo homem maduro e de vida profissional experimentada, e ele as 
registra "na urgência da hora e no calor dos fechamentos do jornal", entrelaçando lembranças de família, atualidades e acontecimentos da história do Brasil e do mundo, marcantes em sua trajetória. É possível aquilatar vínculos dessas vivências em sua poética, tanto narrativa quanto dramatúrgica (RODRIGUES, 2009, p. 11, 56, 58).

Os fragmentos seguintes fundamentam a importância dos sentidos e sentimentos na constituição do sujeito e artista Nelson Rodrigues, sintetizados pelo escritor na seguinte frase: "uma das minhas marcas é a minha infância profunda" (STEEN, 2008, p. 66). Primeiramente, registrados nas Memórias (2009), essa profundeza infantil está intimamente resguardada na alma do autor:

E volto a 1913, ao mesmo Recife e ao mesmo Pernambuco. [...] Ali, eu começava a existir. Ainda não vira um rosto, um olho, uma flor. Nada sabia dos outros, nem de mim mesmo. E, súbito, as coisas nasciam [...] Que idade teria eu? Um ano, um ano e pouco, sei lá. Ou menos, talvez menos. [...] Há ainda um cavalo na minha infância profunda. Mas também o cavalo foi cheiro. Antes de ser uma figura plástica, elástica, com espuma nas ventas - o cavalo foi aroma como o mar (RODRIGUES, 2009, p. 24).

E, depois, com idêntico e esmerado grau de profundidade, nas Confissões (1993):

Eu tinha meus três anos e estava em Pernambuco. Três anos. Aos três anos, o sujeito começa a inventar o mundo. Minha família morava na praia. E eu começava a inventar o mundo. Primeiro, foi o mar. Não, não. Primeiro inventei o caju selvagem e a pitanga brava. [...] Para os meus três anos, o mar, antes de ser paisagem, foi cheiro. Não era concha, nem espuma. Cheiro. 
$[\ldots]$.

Bem me lembro da primeira vez em que fui ao cinema. [...] Eu era um garoto de seis anos, e tudo me espantava. Quando apagou a luz, nasceu na treva uma misteriosa e tristíssima fauna de tosses. Depois do filme, saímos eu e meu irmão Milton. Olhei e vi: - lá estava ela, num canto da sala de espera. Era escarradeira e flor: - subia por um caule fino para se abrir em lírio. Larguei-me do irmão e fui lá cuspir. Passei a mão na boca e voltei. Vinha feliz, envaidecido, realizado. Ainda me voltei, da porta, para vê-la. Linda, linda, imitando um lírio ou um copo-de-leite.

[...].

Também me vejo na calçada da rua Alegre. Os mesmos seis anos. [...] E me fascinava ir de uma esquina a outra esquina, sempre pelo meio-fio. Eu me equilibrava, no meio-fio, como se este fosse fino e vibrante como um arame. Mas eis o que importa dizer: - fazia esse número acrobático, cuspindo sempre. Também me vejo numa sacada, cuspindo na cabeça dos que passavam (RODRIGUES, 1993, $13,17,18)$.

O minucioso detalhamento e a propriedade com a qual o narrador trata ocorrências, sensações e objetos, encaminham o leitor a indagar acerca da condição de origem do texto, isto é, se, de fato, trata-se da escrita do adulto acercada criança, visto que, conforme Marchi (2011, p. 226), uma memória tão minuciosa e arbitrária, a imprimir tamanha força, transmite "a impressão de que a descrição foi feita no calor dos fatos, no momento mesmo dos acontecimentos", circunstância que, também, é posta em discussão por Gaston Bachelard (2006, p. 2) ao enunciar que um reexame de passagens verdadeiramente amadas e firmemente solidificadas na memória, suscita a tendência de ser colocado em dúvida acerca da 
ação empreendida pelo protagonista: está a recordar ou a imaginar essas estimadas ocorrências.

O escritor e memorialista Pedro Nava via a memória como um misto de ficção e realidade. Em entrevista concedida ao Jornal da Bahia, por ocasião do lançamento de seu livro Chão de ferro em terras baianas, Nava diz que o tempo é o personagem central de suas memórias. Mais adiante, acrescenta fugir ao máximo do autobiográfico e aparecer apenas como narrador, tanto dos fatos que presenciou quanto daqueles que teve conhecimento por intermédio de terceiros, valorizando a essência poética que é o lado mágico do acontecimento (PEDRO NAVA..., 1976).

Leitor e admirador de Proust, Nava opera em sua obra uma recuperação de descobertas. A criação artística ocorre não simplesmente pelo ato de lembrar, mas de reinventar o passado como se ele ainda estivesse se constituindo na forma do presente, como se ainda não soubesse o que aconteceu, como se outro futuro fosse possível (MARTINS, 1973).

Em estudo sobre a obra de Pedro Nava, Joaquim Alves de Aguiar (1998) analisa os processos da memória involuntária e voluntária, presentes na obra de Proust:

Alguma coisa se dá no presente que retira dos abismos o que parecia esquecido, mas que na verdade estava guardado nos subterrâneos do inconsciente. A esse processo costuma-se dar o nome de memória involuntária, por oposição à outra, chamada de voluntária. Enquanto esta é recordação provocada, aquela é aleatória, precipitada, repentina. [...] à memória voluntária, pode-se dizer, ligam-se a cronologia dos acontecimentos, o fato, o documento, e a história; à involuntária ligam-se a 
simultaneidade das lembranças que podem justaporse umas às outras, a recriação do fato e a ficção (AGUIAR, 1998, p. 21).

Outro aspecto a ser destacado, este, no episódio em que o autor vai pela primeira vez ao cinema, é que não há o encantamento nem pela sala interna do cinema (da qual só relata a tosse referencial das tias), nem pelo filme, imagens, artistas, mas pela peça antiga e externa da sala de projeção, afinal, o cinema representa o moderno e a escarradeira representa o século anterior - a Belle Époque. Nos processos regressivos aludidos a Proust é possível perceber que Rodrigues (2009, p. 19) compreende e se equipara ao autor de Em busca do tempo perdido, na medida em que não descreve em sua obra uma vida como ela de fato ocorreu, mas sim, uma vida como é lembrada por aquele que a viveu, visto que o posicionamento rodriguiano ao redigir suas memórias é de que "são memórias do passado, do presente, do futuro e de várias alucinações”. Essa particularidade é analisada por Gagnebin (2014):

[...] é por meio da memória, especificamente da memória involuntária, que a imagem, em Proust, adquire traços auráticos. Enquanto as imagens oriundas da memória voluntária - da inteligência, como diz Proust - são tão aborrecidas como uma coleção de cartões-postais [...] "as imagens surgidas da memória involuntária se distinguem das outras porque possuem uma aura" [...] (GAGNEBIN, 2014, p. 166, grifos da autora).

A imagem esplendorosa do menino na janela é algo que se nos impõe, antes, devido à natureza curiosa de garoto, e, posteriormente, por intermédio das sutilezas postas nas crônicas 
memorialistas e confessionais do autor. Conforme descreve em suas percepções infantis, estar na janela era uma ação recorrente no cotidiano de menino, "cabeçudo como um anão de Velásquez"1 (RODRIGUES, 2009, p. 55). Despertado pela imperiosa curiosidade em desvendar a rua, a ela vinham outros movimentos contínuos, conforme o grau de interesse: da janela ao portão, deste para a calçada (talvez, se grande o atrativo, ir até a esquina) e, depois, planar ou sentar-se no meio fio para assistir aos acontecimentos da vida como espectador privilegiado. Embora o movimento sugira uma partitura cênica, configura-se, quase, uma sequência cinematográfica em planos. Esse olhar perspectivo organiza, do exterior ao interior e para além do entorno da casa da infância do autor, na suburbana e carioca Rua Alegre, em Aldeia Campista, no início do século $\mathrm{XX}$, todo um conjunto cenográfico, no qual se inclui, e é abalroado como sujeito do e no mundo, mundo esse permeado de intenções e emoções, pois conforme Plaza (2013, p. 46) percebemos o mundo e nos distinguimos dentro dele, individualmente, embora rodeado de outros corpos, isto é, "à sensação de estar 'aqui' corresponde outra, a de estar 'ali', em conflito", compreensão que se deve ter do eu, a partir do outro.

“Um espanto Nelson Rodrigues". Com esta frase concisa, SôniaRodrigues, escritoraefilhadoautor, encerra,exclamativamente, embora sem a devida pontuação, um parágrafo do texto introdutório de sua compilação das declarações do pai acerca de sua vida e obra, Nelson Rodrigues: por ele mesmo (RODRIGUES, 2012, p. 9), no qual celebra a inteligência e o talento de um homem de pouquíssima escolaridade formal, mas que revolucionou a literatura em vários 1 Diego Velázquez, pintor espanhol (1599-1660). 
de seus gêneros, e soube como poucos dissertar acercado espírito humano, a partir do que viu, leu e viveu. Entendendo as vivências infantis como marcas profundas e valorosas, Rodrigues revisita a meninice como um reservatório de imagens a nutrir sua criação literária, entretanto, ao esclarecimento poético de Bachelard (2006, p. 95) de que, "um excesso de infância é o germe de um poema", Rodrigues contrapõe com graça e sentimento mordaz, que "o menino está enterrado no adulto como um sapo de macumba", ou, dito de modo diverso, com particular poesia, mas não menos sarcasmo, "está comigo, enterrado em mim, um perene menino humilhado" (RODRIGUES, 1997, p. 11).

A humilhação está marcada no corpo e no espírito, conforme expressão recorrente de Nelson Rodrigues em suas Memórias (2009), mas, também, em diversas situações, desde a busca incansável do amor, à paixão pela morte, até as intempestivas defrontações com tragédias, suas e de seus próximos. Ter sido um menino à procura do amor o fez ir para a escola atraído pela presença feminina das professoras, e, segundo ele, as amou sem exceção. Como o bom comportamento não era o seu ponto positivo, enquanto estudante era tratado pelas meninas como maluco e pelas professoras, uma promessa de tarado, pecha que o acompanhou durante boa parte da vida. Nos primeiros anos no Rio, em ato justificado pelos tempos difíceis para as finanças da família, invejou e desejou o sanduíche de pão com ovo, merenda do colega, em face de sua mísera banana. Teve a cabeça examinada, na escola, por conta de epidemia de piolhos, quando constataram que as orelhas também não andavam muito limpas, no que se sentiu duplamente exposto. Mas nada se compara ao horror da fome que se abateu 
sobre os Rodrigues após a morte do pai e o fechamento do jornal. "De pé, ó vítimas da fome"2. Nelson Rodrigues soube como poucos conviver e atravessar a humilhação imposta pela penúria. Em uma de suas frases lapidares ele diz que "a fome é mansa e casta e quem não come não ama, nem odeia" (RODRIGUES, 2012, p. 164, 266).

O período de miséria que ele equipara aos "retirantes de Portinari"', vivido fortemente entre os anos 1930-1936, alterou de forma dramática a vida do escritor e foi responsável pela tuberculose contraída por ele e o irmão, Joffre. Ao internar-se para tratamento no sanatório de Campos do Jordão, sofreu ante a possibilidade de ter de servir a mesa, varrer e fazer as camas dos demais internos, devido à falta de dinheiro para pagar a instituição. A fome que estourou os pulmões de ambos foi fatal ao irmão, morto em 1936. Mesmo assim, o dramaturgo exalta essa experiência como frutífera para o ficcionista, e diz não acreditar no autor sempre bem alimentado. A pobreza imposta pelo empastelamento do jornal da família, após o assassinato do irmão, Roberto, e a consequente morte do pai, foi um período longo que se revestiu em dificuldades extremas para todos (RODRIGUES, 2009, p. 25).

Entretanto, a consequência mais reveladora de humilhação,procedente da fome e da pobreza,acontece pouco antes

2 Intertextualidade entre os Rodrigues do período de provação e miséria com os personagens desvalidos de Cândido Portinari.

3 Os retirantes (1944), obra de Cândido Portinari (1903-1962), que busca nas misérias dos retirantes vistos na infância do interior de São Paulo, o fundamento para sua criação. Há uma profunda relação de respeito da família Rodrigues para com o pintor, especialmente Roberto Rodrigues, com quem dividiu atelier no centro da cidade do Rio de Janeiro. 
do diagnóstico da tuberculose. Após alguns anos em $O$ Globo, num tempo em que o trabalho não deixava espaço para nenhuma vaidade, Nelson Rodrigues relata usar sempre um único terno, passar quatro dias com a mesma camisa e nunca usar meias, porque simplesmente não as tinha. Então, segundo relata o autor, houve um episódio que lhe ficou marcado para sempre:

[...] - um dia, Roberto Marinho chama meu irmão, Mário, e os dois conversam [...] Roberto começa a falar de mim. Disse que eu precisava cuidar mais de mim mesmo. Falou do meu desleixo, do meu cabelo, da minha roupa. Eu andava de barba por fazer. E, por fim, disse tudo: - "Ontem, o seu irmão estava cheirando mal. " [...] Mário teve uma conversa comigo. Com muito tato, muita doçura, foi falando: - "Roberto me disse isso, assim, assim." Recebi um baque no peito. [...] Olhei-me no espelho e pensava: - "É isso mesmo. Deve ser verdade." [...] Através dos anos e já trabalhado pelo sofrimento, transpunha o episódio para o conto, o romance $[\ldots]$ (RODRIGUES, 2009, p. 180-181).

Considerados pelo autor como reescritos, frutos da relação dele e de Roberto Marinho, esse incidente e seu caráter criador e transformador estão registrados em dois momentos de sua produção. Primeiramente, no romance $O$ casamento, quando um personagem é interrogado por outro que lhe diz ter algo a expressar, mas espera não ser encarado como ofensa. Diante da anuência cordial, comenta que ele usa sempre o mesmo terno e, por isso, entre pausa de suspense e a palavra definitiva, descarrega: - "você, às vezes, até cheira mal". O ofendido reage com "um olho de puro terror", enquanto Nelson Rodrigues, já na posição de narrador cronista, assume a reação do personagem como relato pessoal, e manifesta 
ter sido ele mesmo,o "pobre diabo de um terno só". Depois, em episódio de $A$ vida como ela é..., um sujeito lança ao outro: - "Não sei se é porque você usa sempre o mesmo terno. O fato é que você, às vezes, cheira mal. Quero te avisar, porque sou teu amigo". A vítima suspira: - “Obrigado, Fulano” (RODRIGUES, 2009, p. 181).

\section{Bravura Pueril}

A obra rodriguiana articula de modo original experiência vivida e ficção, além de o autor ter construído e divulgado ao longo de sua trajetória e por meio de entrevistas, depoimentos e declarações, uma personalidade autoral que assume a contradição como um dos traços fundamentais do seu pensamento. Entretanto, seu resumo contraditório mais crucial está na autodenominação "anjo pornográfico", mais anjo que pornográfico, pois, segundo Rodrigues: - "Nasci menino, hei de morrer menino. E o buraco da fechadura é, realmente, a minha ótica de ficcionista. Sou (e sempre fui) um anjo pornográfico." (RODRIGUES, 1997, p. 11-12).

"O pecado é anterior à memória" (RODRIGUES, 2009, p. 32). Essa reflexão é feita por Nelson Rodrigues quando revive períodos desassossegados da infância, preocupado com os problemas do sexo, mas ainda sem a devida consciência sobre as vibrações do corpo:

Fui o garoto mais puro do mundo. [...] Eu não entendia as manifestações dos sentidos, que começaram muito cedo em mim. Muito cedo que eu digo, é de uma forma muito forte. [...] era como se eu fosse outra coisa, outro ser, outra pessoa que coabitasse comigo e que me levava a imaginar 
coisas, a sentir coisas, que eu achava completamente abomináveis. O problema é que eu tenho a maior nostalgia de minha pureza infantil, isto até hoje [...] (RODRIGUES, 2012, p. 19, 22-23).

Devido a esses desencontros assombrosos, foi acusado, aos quatro anos, de ter posto em risco a virgindade de uma menina de três. Interrogado sobre o que, exatamente, havia feito, diz não saber, mas a reação da mãe da garota foi firme e precisa, e segundo a irmã, Stella Rodrigues (1986, p. 7-8), a recíproca do menino não menos direta: - "Mãe de namorada é gente má". De fato, a nudez é uma das expressivas marcas de Nelson Rodrigues e ganha estatuto poético em sua obra, como um todo. E o deslumbramento pela nudez é bastante precoce. Aos sete anos, viu a primeira mulher nua, o que iria influir por toda a sua vida, e classificado em suas memórias como o grande espanto de sua infância. A mácula da nudez irá determinar a escolha do lírico título de seu texto teatral de número quinze, Toda nudez será castigada, além de inclusa, também, como recurso dramático, nas peças $A$ falecida e $O$ beijo no asfalto (RODRIGUES, 2009, p. 32-35).

A nudez da cunhada vista pelo cunhado, por defeito na fechadura da porta do banheiro, em $O$ beijo no asfalto, faz referência à confessa obsessão do autor, que a repete para purificarse da lembrança de sua própria nudez, docemente surpreendida pela velha tia, em visita aos parentes no Rio:

[...] eu estava tomando banho [...] e... [o]... ferrolho da porta do banheiro tinha um defeito qualquer. De repente, alguém empurra e abre. Era uma velha tia que passava uns tempos lá em casa. Enfiou a cara 
e me viu. Logo voltou atrás e fechou tudo. Mas me vira, eis a verdade, me vira. Num segundo, na fração fulminante de um segundo, o menino pôs as mãos em folha de parreira. E nada descreve, e nada se compara ao sofrimento, infantil, e o espanto, e o ódio, [...] (RODRIGUES, 2009, p. 86-87).

Nas reflexões, Nelson Rodrigues diz ter odiado o incidente, o que o fez passar boa parte da infância com feridas internas e externas, manchado pela impureza, o que pode ser expresso pela curiosa imagem de proteger-se do vexame com folha de parreira. A reação de surpresa pelo corpo desnudo evoca a imagem bíblica da folha de parreira como proteção à nudez diante da ignomínia do pecado. Por conta disso, relata em desabafo, desejou ser coroinha ou padre. Esse desejo, de algum modo, vai na contramão das escolhas religiosas da família. Em especial, da família materna, pois a matriarca dos Falcão, sua avó, era protestante severa e o autor, quando criança, ia com a mãe e as tias à Igreja Protestante. Mas não negava que a achava feia, seca e árida, sem nenhum atrativo. Sua fascinação total era pela Igreja Católica, justificada pela presença das pinturas e dos santos, em especial, o Senhor morto na Sexta-Feira da Paixão. Nada o tocava mais do que os dourados das colunas, a pulsação de luzes e de sombras, e ali permanecer em meio aos santos curvados, nos altares, junto ao sono dos círios (RODRIGUES, 2009, p. 87).

Duas questões derivam desse encanto: o rito das celebrações religiosas, tidas como germe do teatro ocidental, já denunciavam, na preferência, o embrião do futuro dramaturgo, e também, o gosto revelado pelos mistérios e ritos fúnebres, que o atraíam, desde 
garoto, e que ao invés de lhe meterem medo, deixavam-no corado de excitação diante do clima fantástico do evento:

Nunca o apelo da morte foi tão forte em mim como na infância. Mas em nossos dias ela perdeu a ênfase. O velório de capelinha é uma profanação abominável. No Rio de meu tempo, os mortos eram velados na sala de visitas ou de jantar e tinham a solidariedade de tudo, inclusive das cadeiras, quadros, jarras, espelhos e moscas familiares. Quantas noites fui dormir com vontade de acordar entre os mortos! Ainda menino, descobri que nada é mais falso que o medo da morte: Esse medo nunca existiu. O que se dá, inversamente, é uma urgência de morrer (NELSON RODRIGUES..., 1980, p. 4).

Após a morte do irmão e do pai, um luto dolorido é imposto à família. Por variadas vezes, Nelson Rodrigues declarou a importância do assassinato do irmão no conjunto de sua obra, uma morte determinante para influir, inclusive, em seu projeto definitivo de teatro, pois, nas reflexões do autor, uma peça teatral feita com o objetivo único de provocar o riso do espectador é rigorosa e brutalmente imoral, tão "absurda como o seria uma missa cômica e transformar uma catedral em gafieira." (RODRIGUES, 2009, p. 141-142).

Os corpos pulsam em Nelson Rodrigues (2009, p. 31-35), e, por isso, amor, nudez e sexo, imagens significantes da infância, assumem categorias tão expressivas em sua obra, o que constitui um universo de descobertas em que nada lhe escapava. $\mathrm{O}$ relato da inocência perdida apresentado em suas memórias assume ares de poema, no qual rito de passagem e erotismo combinam-se para narrar a busca do amor na primeira experiência sexual de garoto 
adolescente:

[...] Eu perdi a inocência, numa expressão clássica e autêntica, no princípio dos meus 14 anos, na Rua Benedito Hipólito, que então era a Broadway do Mangue. Ainda existiam francesas fabulosas lá. [...] Até as brasileiras cearenses falavam com sotaque, porque havia essa ilusão da francesa ou então da polaca. [...] a clientela chamava as senhoras mais liberais, mais arejadas, de polacas. Eu saía o último dos cães destes rendez-vous. Eu entrava lá com uma euforia de anjo e saía [...] o último dos pulhas (RODRIGUES, 2012, p. 26).

Os lugares, as casas e os endereços, com precisão de nomes de ruas e detalhadas descrições, têm lugar nas memórias rodriguianas, em voltas regressivas à Aldeia Campista, à Rua Alegre e à Rua D. Zulmira, afetivos microcosmos urbanos. A esse respeito o autor afirma: - "uma rua, ainda a mais obscura, ainda a mais secundária, tem todos os tipos e todas as paixões" (In: RODRIGUES, 1986, p. 52). Em 1953, quando transmuta para o teatro o enredo de um conto de $A$ vida como ela é... dá à protagonista o nome de Zulmira, nunca explicado diretamente, mas amoroso tributo à rua das brincadeiras de sua infância, sempre mencionada nas memórias e nas confissões, e que se constitui no seu texto dramático favorito - A falecida (RODRIGUES, 2012, p. 76).

A casa dos Rodrigues era um ambiente de jornalistasescritores, artistas e leitores,e Nelson Rodrigues queria ser como os irmãos mais velhos.Motivado por essas influências, somadas à curiosidade, Rodrigues devorava os livros da biblioteca do pai e irmãos mais velhos,lançando-se com profundo entusiasmo a tudo 
o que lhe caísse às mãos, conforme Castro (1992, p. 28-29),“dos folhetins mais cabeludos aos almanaques de xarope", deixandose inebriar por particularidades que marcarão sua escrita futura. O gosto pelos folhetins, de início, não era somente escolha, mas oferta que chegava com maior facilidade por conta dos jornais da época que os publicavam como chamariz popular, e nos jornais de Mário Rodrigues não poderia ser diferente, pois ainda que os fatos verídicos mostrados fossem tão apavorantes quanto um folhetim, "o folhetim de verdade também ocupava diariamente seu lugar de praxe no jornal, que passara 1926 inteiro publicando Crime e Castigo, de Dostoiévski, que foi onde Nelson o leu" (MEYER, 1996, p. 371).

Dispensado das obrigações estudantis, embora a contragosto da família, mas com o calor do texto da primeira crônica construída na escola a arder latente enquanto estilo, Rodrigues pode, finalmente, adentrar o jornal do pai na qualidade de "repórter policial, em 29 de dezembro de 1925, aos treze anos e meio, com salário de trinta mil reis por mês".Antes, precisou providenciar "calças compridas para impor respeito aos colegas", ainda que,"filho do patrão" (CASTRO, 1992, p. 45).

Duas imagens configuram o embrião formativo do escritor. Primeiramente, a do menino sonhador, posta em Steen (2008, p. 67), na qual Nelson Rodrigues declara:- "Eu voltava da escola, ficava no quintal, sozinho, junto ao tanque, sonhando, construindo histórias". Em seguida, o avanço intelectual e as referências derivam, naturalmente, da qualidade de suas leituras juvenis e do exercício da escrita, talvez dando forma às histórias imaginadas, conforme relata Castro (1992), enfatizando a "atmosfera de fog", espécie de "indolência melancólica" a invadir o espírito adolescente do escritor, 
o que o fazia retirar-se para leituras e escritas, às escondidas:

Para que não o amolassem em sua angústia, Nelson escondia-se nos quartos ou na Quinta da Boa Vista com os livros que subtraía às estantes de seu pai ou de Milton. Alguns desses livros eram "Os miseráveis" e "O homem que ri", de Victor Hugo; "Naná" e "Germinal", de Émile Zola; os "Contos de Hoffman"; "Amor de perdição", de Camilo Castelo Branco; e muito Machado de Assis e, principalmente, Eça de Queiroz. Tinha outro motivo para querer que o esquecessem: um impulso fanático para escrever. Enchia resmas de papel com o que, olhado de esguelha, pareciam ser crônicas. Não se sabe ao certo o que eram, porque Nelson não mostrava uma linha a ninguém. Nem a Roberto, seu primeiro irmão em admiração (CASTRO, 1992, p. 40-41).

Em breve todo esse exercício de leitura e escrita será posto em movimento, conforme expressa o editorial para o primeiro número do jornal Alma Infantil, lançado no Rio de Janeiro, em 11 de junho de 1926, em que dividia a direção com o primo Augusto Rodrigues Filho, mais novo que ele e residente na capital pernambucana, juntamente com outro companheiro de ambos. Embora adjetivado como um tabloide direcionado às crianças, seus sócios e diretores queriam mesmo era expressar a falta de tolerância para com os rumos do mundo, especialmente a cidade do Recife e do Rio de Janeiro, regidas por adultos barbados sem qualquer possibilidade de regeneração, pois o Nelson Rodrigues editor-adolescente acreditava que na direção de um jornal, mesmo adjetivado como infantil, deveria agir como um "espadachim verbal", ou, do contrário, não honraria a sua descendência 
Rodrigues, por isso Alma Infantil seria uma espécie de $A$ Manhã, mesmo que "de calças curtas" (CASTRO, 1992, p. 60).

Devido a isso, os meninos-jornalistas desafiavam várias instituições, do clero ao executivo da capital pernambucana, alcançando a Câmara e o Senado da capital da República. Criado como um "grito de revolta" há tempos guardado nos corações de seus diretores, que "sofrem dolorosamente" pela falta de progresso no país e devido à mediocridade reinante, conforme posto em Castro (1992, p. 60-63), eles imploram pela honra e nobreza dos homens públicos, "cujo ardor patriótico está mergulhado num lethargo desanimador", isso porque, segundo o juvenil editor Nelson Rodrigues, a

[...] mentalidade dos homens políticos brasileiros deita-se indecentemente na cama e nos braços da mediocridade. O nosso progresso ultimamente com a frialdade do enthusiasmo dos brasileiros, apanhou reumathismo, ficando absolutamente impossibilitado de andar. Todos esses marmanjões de barbas, bigodes, com um porte de rei em cima da pança estourando de "chopp" falam muito, mas realmente só têm feito até agora uma coisa notável: roubar e descançar (CASTRO, 1992, p. 63; sinais e grafias originais do documento $\left(\right.$ ac-simile $^{4}$.

Num clima de bravura pueril e ufanista, o editorial termina em tom de ameaça, mas os adjetivos e as exclamações tão em voga na imprensa da época, e que serãomarcas de estilo na sua 4 A referida citação consta da obra $O$ anjo pornográfico: a vida de Nelson Rodrigues (CASTRO, 1992, p. 63), inclusa no texto do fac-símile do primeiro número do jornal Alma Infantil. O processo para obtenção dessa fonte se deu pela ampliação do referido material, o que tornou possível sua posterior transcrição. 
futura criação dramática, juntamente com as reticências, já estão manifestas, conforme demonstra o excerto abaixo:

[...] ALMA INFANTIL será uma casa que acolherá sempre de braços abertos as idéias partidas duma alma infantil!... Vibra nessa folha o enthusiasmo moço, sadio, que caminhará sempre numa estrada reta e única!... [...] Faremos uma guerra louca, sem tréguas, a todos aquelles que julgarmos nocivos a sociedade e ao progresso do Brasil! ALMA INFANTIL nasce como sol, cheia de luz, forte, derramando em torno de si alegrias e sofrimentos! ESTAMOS SERENOS PARA ESSA DISPUTA TITÂNICA QUE ESPERAMOS VENCER SOMENTE COM UMA ARMA: uma pena moça, sadia, sincera, molhada pela tinta da dignidade (CASTRO, 1992, p. 63, sinais e grafias originais do documento fac-símile).

Alma Infantil resiste até o quinto número, quando seu principal mentor perde o interesse e abandona o projeto, sendo levado pelas mãos do pai às paginas dos editoriais de $A$ Manhã. As primeiras crônicas foram motivo de orgulho, mas uma recaída não demorou a ocorrer, e dessa vez, o atingido foi um ídolo de Mário Rodrigues,o jurista e político Rui Barbosa. Como punição foi retirado da prestigiada página de crônicas e devolvido à sessão policial, que havia sido sua porta de entrada no jornal (CASTRO, 1992, p. 61, 65, 67). Mais tarde, Rodrigues irá louvar essa trajetória, ao dizer que todo o seu teatro tem a marca de sua experiência como repórter policial, na qual sedimentou a veia de ficcionista por conta da proximidade com o cadáver e a morte.No dia seguinte ao falecimento do escritor, o Jornal do Brasil(22/12/1980) estampava em seu Caderno $B$ um texto obituário em que a voz do dramaturgo 
ressoa em conjunto com a do repórter ao falar dessa experiência e suas consequências poéticas:- "O jornalismo policial mudou minha vida. Através dele me tornei uma espécie de amigo íntimo da morte", o que é complementado em análise do redator:

Se não amigo íntimo, pelo menos um obcecado por ela. A morte seria a matéria prima de alguns de seus melhores momentos como jornalista, ofício em que se iniciou ainda nos tempos de $A$ Manhã. A morte estaria presente, também, em quase todas as suas peças, povoadas de cadáveres e velórios, viúvas sombrias e personagens trágicas. Sua experiência como repórter policial durou pouco, porém. Logo ele passou a escrever crônicas sobre temas de sua própria escolha, em $A$ Crítica e mais tarde em $O$ Globo.Eram crônicas sobre fatos e pessoas da cidade, repletas de paixões, ciúmes, adultérios, suicídios, incestos e loucuras (NELSON RODRIGUES..., 1980).

As experiências vividas e revividas pelo escritor e jornalista entre a infância e a adolescência nas redações dos jornais e nas funções que exerceu,misturam traços de genialidade com rebeldia juvenil. Por vezes, Rodrigues (2012, p. 30; 75) refletiu acerca de sua condição de criança vivaz e adolescente imprestável, segundo sua avaliação: - "Fui um péssimo adolescente e só despertei da infância aos quarenta anos".O período de transição etária, que vai da radicalização contra os bancos escolares, até a edição de Alma Infantil, alcança a fase dos textos publicados com anuência e elogios do pai em prestigiosas colunas de $A$ Manhã e Crítica, e se junta aos deslizes em espinafrar o ídolo paterno, segundo analisa Alexandre Callari (2012), constitui etapa de alternância na qualidade e no estilo dos textos publicados por Rodrigues. 
O primeiro artigo de Nelson Rodrigues foi publicado em 7 de fevereiro de 1928 e se chamava A tragédia de pedra... . ....] No dia 16 de março, a crônica $O$ rato... marcou o início de uma revolução na obra do escritor, que pela primeira vez demonstrou algum fascínio pelo bizarro ao relatar a imagem de um rato morto em frente à Biblioteca Nacional. Os textos de Nelson começam a ficar cada vez mais peçonhentos, e, como consequência, seu pai o mandou de volta à seção policial (CALLARI, 2012, p. 12).

Essa variabilidade no seu processo de criação marca a busca pelo desagradável ${ }^{5}$, e se nos apresenta como o germe daquilo que o dramaturgo vai deplorar na criação literária, que é a obra de arte perfeita. Nelson Rodrigues (2012, p. 63-64) dizia ter mais fascínio pela imperfeição: - "Eu prefiro que haja uma luta feroz do autor com seu tema, com sua linguagem. Que ele dê com a cara no chão de vez em quando. Quando sinto falhas dentro da obra de arte, me impressiona mais" (RODRIGUES, 2012, p. 78).

\section{Considerações Finais}

Conforme Carlos Heitor Cony (RODRIGUES, 2004, p. 9-11), o Nelson Rodrigues dos primeiros anos não é inédito, mas surpreendentemente novo e atual, antes mesmo de atingir a maioridade civil, numa obra que expressa não apenas a escrita, mas a personalidade autoral, "como se o Nelson adulto já estivesse

5 Expressão cunhada por Nelson Rodrigues para designar, provocativamente, algumas de suas peças escritas após Vestido de noi$v a$, cujos temas mórbidos, imorais e monstruosos, segundo o autor, eram capazes de provocar doenças na plateia (GUINSBURG; FARIA; LIMA, 2006, p. 108). 
dentro daquele rapaz magro, com farda de colegial, tal como a fruta dentro da casca". O próprio autor endossa a proposição de Cony, em resposta à pergunta de Steen (2008), que o questiona acercada origem da temática da tragédia carioca. Nelson Rodrigues responde à entrevistadora evocando o espírito da infância e préadolescência como motor criativo: - "A indução vem desde a minha pré-adolescência, a infância inclusive. [...] Eu fui para a reportagem de polícia aos treze anos. Ora, por quê? A preferência pelo assunto já era uma antecipação da minha obra" (STEEN, 2008, p. 72).

Neste trabalho, buscamos destacar e analisar as vivências infantis e juvenis como elementos conectores formadores da personalidade autoral do jornalista e escritor Nelson Rodrigues, material que repercute na construção dos textos narrativos de cunho memorialista e se ajusta na construção de sua obra narrativa e dramática. Em suas memórias, o escritor celebra os fatos marcantes vivenciados na infância e adolescência, alcança parte da juventude, em clima retrospectivo. Os primeiros anos na imprensa são reveladores de aprendizado assistido e orientado pela presença do pai e irmãos mais velhos. O olhar perspectivo e o modo original de observar o mundo e o entorno se expressam nas paixões, introspecção e isolamento, que marcam o embrião do cronista e dramaturgo. Os ritos de passagem estão circunscritos entre os eventos dramáticos familiares e circunvizinhos, como nascimento, morte, violência, amores e paixões, envolvendo nudez, doença, fome e humilhações, conforme sintetiza o autor: - "[...] o artista morre quando se faz adulto. Se ele é incapaz do espanto, do horror, do medo, que só as crianças têm, não escreverá uma linha válida" (RODRIGUES, 1986, p. 139). 


\section{Referências}

AGUIAR, Joaquim Alves. Espaços da memória: um estudo sobre Pedro Nava. São Paulo: Editora da Universidade de São Paulo: Fapesp, 1998.

BACHELARD, Gaston. A poética do devaneio. 2. ed. São Paulo: Martins Fontes, 2006.

CALLARI, Alexandre. Desvendando Nelson Rodrigues: vida e obra no cinema e na televisão. São Paulo: Évora, 2012.

CASTRO, Ruy. O anjo pornográfico: a vida de Nelson Rodrigues. São Paulo: Companhia das Letras, 1992.

GAGNEBIN, Jeanne Marie. Limiar, aura e rememoração: ensaios sobre Walter Benjamin. São Paulo: Editora 34, 2014.

GUINSBURG, Jacó; FARIA, João Roberto; LIMA, Mariângela Alves de (org.). Dicionário do teatro brasileiro: temas, formas e conceitos. São Paulo: Perspectiva, 2006.

MARCHI, Rita de Cassia. Walter Benjamin e a infância: apontamentos impressionistas sobre sua(s) narrativa(s) a partir de narrativas diversas. Educação, Porto Alegre, v. 34, n. 2, p. 221229, maio/ago. 2011. Disponível em: http://revistaseletronicas. pucrs.br/ojs/index.php/faced/article/viewFile/7535/6360. Acesso em: 18 jul. 2018.

MARTINS, Wilson. As neves de antanho - IV. Jornal O Estado de São Paulo, São Paulo, SP, 19 ago. 1973. (Suplemento Literário: Últimos Livros).

MEYER, Marlyse. Folhetim: uma história. São Paulo: Companhia das Letras, 1996. 
NELSON RODRIGUES (1912-1980): Autor e personagem não morrem com a morte. Jornal do Brasil, Rio de Janeiro, 22 de dez. 1980. Caderno B, p. 4.

PEDRO NAVA: a experiência sofrida de um memorialista. Jornal da Bahia, Salvador, 4 ago. 1976. Entrevista concedida, p. 3.

PLAZA, Julio. Tradução intersemiótica. São Paulo: Perspectiva, 2013.

RODRIGUES, Nelson. O óbvio ululante: primeiras confissões. São Paulo: Companhia das Letras, 1993.

RODRIGUES, Nelson. Flor de obsessão. São Paulo: Companhia das Letras, 1997.

RODRIGUES, Nelson. O baú de Nelson Rodrigues: os primeiros anos de crítica e reportagem (1928-35). São Paulo: Companhia das Letras, 2004.

RODRIGUES, Nelson. Memórias: a menina sem estrela. Rio de Janeiro: Agir, 2009.

RODRIGUES, Sonia (org.). Nelson Rodrigues por ele mesmo. Rio de janeiro: Nova Fronteira, 2012.

RODRIGUES, Stella. Nelson Rodrigues, meu irmão. Rio de Janeiro: José Olympio, 1986.

SALLES, Cecília Almeida. Crítica genética: fundamentos dos estudos genéticos sobre o processo de criação artística. 3. ed. São Paulo: EDUC, 2008.

SALLES, Cecília Almeida. Da crítica genética à crítica de processo: uma linha de pesquisa em expansão. Signum: Estudos da Linguagem, Londrina, n. 20/2, p. 41-52, ago. 2017. Disponível 
em: http://www.uel.br/revistas/uel/index.php/signum/article/ viewFile/27384/21315. Acesso em: 23 out. 2018.

STEEN, Edla Van. Viver \& escrever. 2. ed. Porto Alegre: L\&PM, 2008. v. 3. 